Robert JANIK

\title{
3.1. SOCIAL AND ECOLOGICAL PROBLEMS IN THE EU FROM THE PERSPECTIVE OF CONTEMPORARY MANAGEMENT
}

\section{Summary}

The process of European unification is successful in many areas but also faces a lot of problems and challenges. To the very important ones belong the social inequalities, unemployment and the destruction of nature. It is sensible to search for solutions that connect economic interests of modern societies with the necessity of adhering to ecological norms. Improvement of the natural environment will require not only ecologically safe technology but also a change in lifestyle - also in the industrial world. This problem could be confronted within the framework of the new approach to solving the problem of unemployment but however, political will is necessary. This issue is also prevalent in Europe which with regard to its small area must maintain utmost care in the issue of the cleanliness of the natural environment.

Thanks to the development of science and technology the creation of new economic activities in Europe is possible. They can help to create new possibilities for both, the solving of the ecological problems and to create jobs in many sectors of economy. The contemporary management should play a very important role in this process.

Keywords: unemployment, ecology, management, pollution, environment, profit, globalization, European integration

\section{Global changes}

The lack of regard for ecological aspects in human activity is leading to the destruction of the natural environment as well as using and wasting human potential in the strife for constant growth in production and maximizing profits. Improvement of the natural environment will require not only ecologically safe technology but also a change in lifestyle - also in the industrial world. This problem could be confronted within the framework of the new approach to solving the problem of unemployment but however, political will is necessary.

Since the end of the World War II, the globe seems to shrink rapidly, increasing the mutual relationships between its particular regions surprisingly quickly. As a result, over the past decades, the term ,globalisation" has emerged, becoming a synonym for progress and prosperity for its proponents, while for its opponents it became a slogan for a reactive system of capitalistic exploitation. (Giddens, 1993, p. 547) "Transboundary pollution, global warming, climate change, and species extinction are challenges that cannot be contained within national or even regional borders. They do not have isolated causes and effects. They are global problems, caused by aggregate 
collective human actions, and thus require a coordinated global response. To be sure, ecological problems aggravate by globalization also have significant economic ramification. Although these effects will be more significant for less developed countries than for rich countries, they will nonetheless affect all people and all nations. (...) They are economic, political, cultural but above all ethical issues that have been expanded and intensified by globalization processes." (Steger, 2009, p. 90) The 21st century appears to be a particular time in the history of mankind. The processes commenced in the previous centuries are leading to a transformation of the style of life of mankind on an unprecedented scale. (Toffler, 1995) There are also positive achievements of civilization as evidenced by the elimination of certain illnesses, limitation of famine and the general if unbalanced technical development. (Kromołowski, 2014) However, there is also a multitude of negative effects of running such policies as exploiting the natural resources of the Earth in a manner that is not thought out but rather more like plundering. "Large areas of the Earth's surface, especially in arid and semi-arid regions, have been used for agricultural production for millennia, yielding crops for ever-increasing number of people. Concerns about the relationship between population growth and environmental degradation are frequently focused rather narrowly on aggregate population levels. Yet, the global impact of humans on the environment is as much a function of per capita consumption as it is of overall population size. For example, the Unites States comprises only 6 per cent of the of the world's population, but it consumes 30-40 per cent of our planet's natural resources. Global overconsumption and uncontrolled population growth present a serious problem to the environment. Unless we are willing to change the underlying cultural and religious value structure that has combined with the social and economic dynamics of unrestrained capitalist accumulation, the health of Mother Earth is likely to deteriorate even further." (Steger, 2009, pp. 85-86.)

Modern times are also characterized by a large dissonance emerging between the commonly declared slogans such as "human dignity" and "human rights" while the practices in force in many parts of the world greatly differ from these declarations. (Fukuyama, 2007) This refers to a large extent to the issue of military conflicts as well as social and ecological imbalance. (Akerlof and Shiller, 2009)

In the capitalist maximization of profits "at all costs" the notion of the stock exchange turned out to be of great use. This to a large extent refers to the axiological sphere which is affected by the consequences of socio-economic processes. Such features as the hedonistic cult of availing of life, lavishness, maintenance of political fiction and social imbalance, as well as damage to the natural environment are all particularly criticized. The transformation of certain features is visible, which can be initially acknowledged as positive and leading to the building of the "ethos of capitalism". Nowadays, this has become its own caricature as exemplified by the desire of consumptionism which replaced "Calvinist frugality" or striving for profit that is satisfied by speculation on the stock exchange that has replaced traditional hard work. This situation would appear to hold a significant opportunity for change in terms of the plundering exploitation of natural and human resources that has been dominating up to now, particularly referring to the approach of a greater distance from glorification and the use of the religious cult of "insignias of capitalism" such as stock exchanges or the 
free market. It would be possible within the framework of existential reflection to return to "the source" of humanism and release man from the slavery of the soulless dictatorship of the calculation of profit "at all costs", which is damaging not only from the point of view of culture, but also for the species of the homo sapiens. "What is currently at stake is the conservation of the Earth and the biosphere, the thin layer that is the scene of all of life. Desertification, deforestation, erosion, ozone depletion, acid rain and the greenhouse effect are just a few of the threats facing us. Another spectre is that of nuclear war, which would certainly be the end of everything. Human suffering and the destruction of Nature are everyday realities. At the same time, the call for action is becoming louder. Something must be done before Man effectively destroys the world; this awareness is gaining ground at all levels." (de la Court, 1990, p. 9)

Bearing in mind the frequently non-transparent and unpredictable nature of stock exchange operations in which speculative capital is particularly damaging, they are becoming a symbol of a lack of comprehension by the average human being in terms of the functioning of the contemporary economy. Likewise, in the case of the political mechanisms, critical thinkers debate at length on the exquisite forms of manipulation including social engineering through the means of many economic and political groupings that repeatedly lay claim to the name of "defenders of democracy".

The price paid for availing of the stock exchange is that of uncertainty. Much points to the fact that this lack of certainty goes beyond the borders of " casino capitalism", thus directly affecting the existence of "human capital". Employees must increasingly become aware of the fact that what they were indoctrinated within the nature of certainties loses its meaning as exemplified by the recent theory on the need to identify with the workplace which quickly became invalid and "attaching yourself" and "identify with" have been replaced by the slogans "mobility" and "adjusting yourself" with regard to the changing situation on the labour market.

Another symptom of the changes reflecting the spread of globalization is the occurrence of "political integration", whose symptomatic symbol could be termed as the process of unification in Europe. Likewise, in other parts of the world the processes of "integration" are emerging - as exemplified by the American continent. The emergence of large transnational structures in the shape of the European Union admittedly does not signify the immediate disappearance of nations, but does however constitute a major step in the direction of transferring elements of the previously held power from a national level to that of a supra-national level. This is accompanied by the awareness among citizens of belonging to a greater organizational structure that transgresses the previous national boundaries, as well as creating within a continent a European cultural community. It is necessary to mention the practical side of this phenomenon - migration flows, spreading of familiarity with foreign languages, mixed marriages, use of different systems of education, as well as the impact of mass cultures on the inhabitants of various countries. This leads to the erosion of the existing concepts of national states and the birth of new forms of ethnic and cultural identities. In the logic of the integration processes, the shift of the burden from the centre to the lower organizational levels is a natural sequence of events. This particularly refers to those countries which consist of culturally "independent" provinces or possess significant ethnic minorities e.g. in the case of the EU there is a clear strife towards the 
Janik, R.

passing on of some of the responsibility for decision-making and their realization in the case of the regions in question. This helps to release ethnic tension to a certain extent in the case of the occurrence of separatist trends in some countries. "On one hand, the worsening food crisis highlights the interconnections between political, economic and ecological problems. Indeed, globalization processes such as the expansion of trade and transport drive overconsumption and environmental degradation. However, on the other hand, the food crisis also shows how global response to environmental problems may also lead to new problems such as the aforementioned biofuel issue or the considerable risk associated with nuclear alternatives to carbon-based energy sources. Ironically, such attempts to reduce our species" "carbon-footprint" contain different threats to the environment." (Steger, 2009)

The process of European's unification process is in many areas successful but also faces a lot of problems and challenges. To the very important ones belong social inequalities, unemployment and destruction of the nature. In contemporary times, we are also faced with the rich variety of production techniques - many of which are deemed to be "damaging for the natural environment" are in fact even tolerated by the same politicians who refer to the need to protect the "natural resources" of our planet. Much points to the fact that in the period of the industrial revolution an unwritten rule was created with regard to the priority of economic interests over the protection of the natural environment, thus facilitating the realization of policies of economic growth while ignoring the impact this has on nature to a serious extent. However true to say that the dramatic effects of degradation of the Earth's resources finally forced the inclusion of ecological issues in the economic sphere, the practice of "choosing the lesser evil" is still very much in evidence today- the so-called situation of conflict between economic and ecological interests, at the expense of the latter ones.

Significant changes have occurred over the last few years in the sphere of agriculture. The so-called „mad cow's disease” or foot and mouth disease showed the limits of industrial fattening of animals - the spongy degeneration of the brain is however only one of many possible dangers that are associated with the policy of maximizing profits in agriculture at all costs. Mass production of cheap food entails negative consequences for the health that are difficult to foresee - mainly due to the use of chemical substances in agriculture. The acceptance of genetically manipulated food on the market which has not been sufficiently tested in a process of long term tests would appear to be particularly controversial. It is also important not to forget about the ecological costs of mass fattening of animals. It is necessary to consider the sense of changing the form of production - perhaps working out a pro-ecological form of agricultural production which would take the form of producing healthy food that does not destroy the natural environment and would provide increased possibilities of employment. We should move away from large breeding farms which produce unhealthy food in a manner that is harmful to the environment. "Another significant ecological problem associated with population increases and the globalization of environmental degradation is the worldwide reduction of biodiversity. Seven out of the biologists today believe that the world is now in the midst of the fastest mass extinction of living species in the 4.5-billion-year history of the planet. According to 
recent OECD reports, two-thirds of the world's farmlands have been rated as "somewhat degraded". Half the world's wetlands have already been destroyed, and the biodiversity of freshwater ecosystems is under serious threat. Three-quarters of worldwide genetic diversity in agricultural crop and animal breeds has been lost since 1900. Some experts fear that up to 50 per cent of all plant and animal species - most of them in the global South - will disappear by the end of this century." (Steger, 2009, p. 87)

John Maynard Keynes (1883-1946), the author of "The general Theory of Employment, Interest and Money" (1936) is known as the creator of the concept of economic interventionism and the "father of welfare state". This outstanding scientist is considered to be a co- founder of microeconomics, he created a new concept of economic cycles and regarded dynamics of capital investment as the main factor eliminating the influence on market demand. (Harrod, 1972)

Keynes' economic concepts included far-reaching social implications- he advanced the view of economic interventionism; he was convinced that the free marked should be controlled by government. This scientist had a great impact on the shape of economics in Great Britain. As an economist, Keynes was in favour of improving the living conditions of the poor, which also was of vital practical importance. "When men are unemployed, society does not miss the goods they do not produce. The loss here is marginal. But the men who are without work do miss the income they no longer earn. Here the effect is not marginal. It involves all or a large share of the men's earnings and hence all or a large share of what they are able to buy. And, we note, high and stable production is the broad foundation of the economic security of virtually every other group - of farmers, white-collar workers, and both large businessman and small." (Galbraith, 1963, p.165)

A kind of a so called Keynesianism in the area of social life and environmental protective economical activities could change the to-day situation within the EU for the better.

The important macro-political moves by EU member countries, which have an influence on the liquidation of unemployment and the development of the process of integration can be listed as follows:

- Continuation of unification of EU law;

- Expansion of the common trading policy;

- Intensification of efforts for the creation of the common market by abolishing restrictions in the movement of goods, people, services and capital between EU member countries;

- Carrying out a common social policy in the EU;

- Supporting the construction and expansion of communication routes in Europe; cooperation in the area of agriculture and fishing;

- Working out a system that prevents counterfeiting by criminal gangs;

- Making contributions towards maintaining the high level of healthcare in the EU, strengthening industrial competitiveness in the EU - among other methods, by the implementation of new technologies;

- Subsidizing research and technological development; 
- Unifying policies in the area of aid for developing countries; intensifying efforts for the improvement of consumer protection;

- Common activity in the sphere of energy, prevention of catastrophes and the expansion of communication routes.

In contemporary times, we are also faced with the rich variety of production techniques, many of which are deemed to be "damaging for the natural environment" are in fact even tolerated by the same politicians who refer to the need to protect the "natural resources" of our planet. Much points to the fact that in the period of the industrial revolution an unwritten rule was created with regard to the priority of economic interests over the protection of the natural environment, thus facilitating the realization of policies of economic growth while ignoring the impact this has on nature to a serious extent. However true to say that the dramatic effects of degradation of the Earth's resources finally forced the inclusion of ecological issues in the economic sphere, the practice of "choosing the lesser evil" is still very much in evidence todaythe so-called situation of conflict between economic and ecological interests, at the expense of the latter ones.

A particular area of activity in welfare states should be efforts aimed at preventing the negative effects of the process of globalization. Many proposals have been repeatedly offered by governments of particular countries aimed at the elimination of the possibilities of various abuses - both on the part of particular producers and states themselves. (Drucker, 1993)

\section{Conclusions}

Maintenance of the established social standards as a result of international agreement forcing capitalists to take responsibility for the businesses run on the countries of their choice - mainly by adhering to legal and tax systems. Without questioning the sense of such a step it is important to note that in present times the failure to take any measures comes in conflict with western states which have possibilities at their disposal to force economic magnates to run a more pro-social form of economic activity. Firms that focused on profit apply the concept of ,moving capital”, which means moving the production to countries where they have access to a cheaper workforce and greater tax grace. More detailed analysis indicates that this is by no means the end of the moving capital - very frequently products made in this way are returned to the mother country (for the particular firm) with the aim of selling the goods there as the place where the goods originated does not usually have appropriate dynamics of purchasing power due to poverty of those societies. This is connected with the fact that western countries are still the most powerful market, which makes them attractive for various producers. If such a procedure was not possible the western countries instead of receiving such products with open arms would block their access to the market by indicating the dishonesty of such practices and firms with moving capital would in the fear of losing profits be definitely more careful about making decisions to move production facilities abroad. Regardless of the use of these possibilities of action the developed countries should strive to reduce the costs of production, as these amounts are often associated with the need to finance various undertakings in the form of ,additional costs" - e.g. 
social care. Aside from this, it is important to add that the amount of earnings of employees in western Europe is not very economically motivated relatively speaking it is influenced by other factors- e.g. tariff conditions. (Janik, 2011, pp. 109-123.)

The contemporary management should find new creative possibilities for solving social and ecological problems within the EU.

The lack of regard for ecological aspects in human activity is leading to the destruction of the natural environment as well as using and wasting human potential in the strife for constant growth in production and maximizing profits. It is sensible to search for solutions that connect economic interests of modern societies with the necessity of adhering to ecological norms. Regardless of this, it is possible to gain new work places in the area of environmental protection - and this is not only through the means of „traditional" activities associated with concern for the cleanliness of forests and built up areas but also in the utilization of various forms of industrial waste. In many western countries this type of processing has developed into a prospering business that brings in significant profits - a serious business is for instance the processing of used paper. In some areas of the USA this has yielded millions of dollars - similar activities have been undertaken in the case of processing scrap metal. Likewise, in other areas of environmental protection the possibilities of creating greater numbers of work places associated with environmental protection are increasing - an example of this could be the recultivation of industrial areas, modern management of constant waste, maintaining systems of supplying water and waste water removal, protection of water and sewage systems.

Significant changes have occurred over the last few years in the sphere of agriculture. Mass production of cheap food entails negative consequences for the health that are difficult to foresee - mainly due to the use of chemical substances in agriculture. "For many small-scale farmers the Green Revolution proved disastrous. They could not pay for the fertilizers and pesticides; they were not even creditworthy. When the Green Revolution did achieve was to increase the profit-making potential of agriculture, making the land more attractive to rich farmers. The result: many leaseholders were evicted from their land, and small farmers bought out. The range of food products available to the people in rural areas was also affected. Farmers in Indonesia, for instance, used to keep carp in their wet rice paddies, providing a major source of protein; after the introduction of pesticides, all fish perished." (de la Court, 1990, p. 41) Constructive steps on the road to improving the situation in agriculture are hindered by the ,agrarlobby" which benefits from the current situation, which is witnessed not so much in terms of the numbers of citizens employed in agriculture as in terms of the economic and political potential at its disposal. Recently, there has been an increase in the significance of eco-tourism, whose services are availed of by an increasing number of health conscious people. Unhealthy living conditions that exist in large city agglomerations encourage people to search for alternatives both in the form of „healthy” holidays or a few days of rest e.g. on Saturdays and Sundays, while also in the form of changing lifestyles and way of living - evidence of this is shown in the increase of ,green belts" in city areas. The afore-mentioned changes create new jobs and lead to the formation of healthier habits that are safer for the natural environment. 
Laws to prevent environmental destruction should be connected with pro-ecological economic activities. This a very important source of the creation of new jobs. (Galbraith, 1963) A very important issue is also the production of "clean energy", as an alternative to the "dirty" ones as well as to the nuclear energy. There is still a large amount of unused social and economic possibilities that are hidden in "unconventional" sources of energy - or in other words, its production in hydroelectric, air and solar power plants. These constitute a significant alternative with relation to the traditional methods of power production - mainly atomic and coal powered power plants. Because of the relative small size of Europe the care for the environment should be a particular important issue on the continent.

Thanks to the development of science and technology the creation of new economic activities in Europe is possible. (Bylok, 2013)

They can help to create new possibilities for both, the solving of the ecological problems and to create jobs in many sectors of economy. The contemporary management should play a very important role in this process. Europe as one of the first continents which started the dynamic process of industrialization and destroying of nature can also be the first one to unite the contemporary economy with proeconomical activities. This would allow to connect the solving of social and ecological problems.

\section{References}

1. Akerlof G.A., Shiller R.J. (2009): Animal Spirits, Princeton University Press, Princeton

2. Brundtland B. (1990): Green Development in the 1990s, New Horizons Press, New York

3. Bylok F. (2013): Chosen Aspects of Managing Social Capital in Enterprises, in: Ubreziova, Horska (Eds) Modern Management in the 21st Century. Theoretical and Practical Issues. Monograph. Garmond, Nitra

4. Drucker P. F. (1993): Post-Capitalist Society, Harper Business, New York

5. Fukuyama F. (2007): After the Neocons. America at the Crossroads, Profile Books, London

6. Galbraith J. K. (1963): The Affluent Society, Pelican Book, Great Britain

7. Giddens A. (1993): Sociology, second edition, Polity Press, Oxford

8. Harrod, R. F. (1972): Jahn Maynerd Keynes, Middlesex: Pelican Books

9. Janik R. (2011): Political and Economic Context of the Debate on „Human Capital” within the EU, in: Bylok F., Cichobłaziński L.: The Role of Human Capital in Knowledge Based Management, Częstochowa: Politechnika Częstochowska

10. Kromołowski H. (2014): Best Practices in Public Hospital Crisis Management, in: Management and Managers Facing Challenges of the 21st Century. Theoretical Background and Practical Applications, F. Bylok, I. Ubreziova, L. Cichobłaziński (Eds). Godollo, Hungary

11. Steger M. B. (2009): Globalization, Oxford University Press, Oxford, New York

12. Toffler A. a. H. (1995): Creating a New Civilization, Turner Publishing, Inc. Atlanta 